Article

\title{
Differential Gene Expression Profiles between N-Terminal Domain and Ligand-Binding Domain Inhibitors of Androgen Receptor Reveal Ralaniten Induction of Metallothionein by a Mechanism Dependent on MTF1
}

\author{
Jon K. Obst ${ }^{1}$, Nasrin R. Mawji ${ }^{1}$, Simon J. L. Teskey ${ }^{1}$, Jun Wang ${ }^{1}$ and Marianne D. Sadar ${ }^{1,2, *(D)}$ \\ 1 Department of Genome Sciences, British Columbia Cancer, 675 West 10th Avenue, \\ Vancouver, BC V5Z 1L3, Canada; jobst@bcgsc.ca (J.K.O.); nmawji@bcgsc.ca (N.R.M.); \\ simonteskey@gmail.com (S.J.L.T.); jeanwang@bcgsc.ca (J.W.) \\ 2 Department of Pathology and Laboratory Medicine, University of British Columbia, \\ Vancouver, BC V6T 1Z7, Canada \\ * Correspondence: msadar@bcgsc.ca; Tel.: +604-675-8157; Fax: +604-675-8178
}

\section{check for}

updates

Citation: Obst, J.K.; Mawji, N.R.; Teskey, S.J.L.; Wang, J.; Sadar, M.D. Differential Gene Expression Profiles between N-Terminal Domain and Ligand-Binding Domain Inhibitors of Androgen Receptor Reveal Ralaniten Induction of Metallothionein by a Mechanism Dependent on MTF1. Cancers 2022, 14, 386. https:// doi.org/10.3390/cancers14020386

Academic Editor: Arnab Basu

Received: 15 December 2021

Accepted: 11 January 2022

Published: 13 January 2022

Publisher's Note: MDPI stays neutral with regard to jurisdictional claims in published maps and institutional affiliations.

Copyright: (C) 2022 by the authors. Licensee MDPI, Basel, Switzerland. This article is an open access article distributed under the terms and conditions of the Creative Commons Attribution (CC BY) license (https:// creativecommons.org/licenses/by/ $4.0 /)$.
Simple Summary: Inhibition of the androgen receptor (AR) remains the mainstay treatment for prostate cancer. All current therapies involving AR inhibition either directly or indirectly target its ligand-binding domain (LBD). We have developed the first novel compounds which target the N-terminal domain, (NTD) a region which is essential for AR transcriptional activity. Firstgeneration ralaniten (NCT02606123), and second-generation EPI-7386 (NCT04421222) remain the only AR-NTD inhibitors to progress to clinical trials. Here we aim to characterize differences between different classes of AR antagonists targeting the AR-LBD and the AR-NTD, as well as next generation AR-NTD inhibitors. An incidental finding was that ralaniten was uniquely associated with increased metallothionein expression which was independent of AR activity. Instead, expression of metallothionein genes was driven by MTF-1 indicating a potential off-target effect. Neither AR-LBD inhibitor enzalutamide nor second-generation AR-NTD inhibitor EPI-7170 had this effect. This work has important implications for the development of novel AR-NTD inhibitors.

Abstract: Hormonal therapies for prostate cancer target the androgen receptor (AR) ligand-binding domain (LBD). Clinical development for inhibitors that bind to the N-terminal domain (NTD) of AR has yielded ralaniten and its analogues. Ralaniten acetate is well tolerated in patients at $3600 \mathrm{mgs} /$ day. Clinical trials are ongoing with a second-generation analogue of ralaniten. Binding sites on different AR domains could result in differential effects on AR-regulated gene expression. Here, we provide the first comparison between AR-NTD inhibitors and AR-LBD inhibitors on androgen-regulated gene expression in prostate cancer cells using cDNA arrays, GSEA, and RT-PCR. LBD inhibitors and NTD inhibitors largely overlapped in the profile of androgen-induced genes that they each inhibited. However, androgen also represses gene expression by various mechanisms, many of which involve protein-protein interactions. De-repression of the transcriptome of androgen-repressed genes showed profound variance between these two classes of inhibitors. In addition, these studies revealed a unique and strong induction of expression of the metallothionein family of genes by ralaniten by a mechanism independent of AR and dependent on MTF1, thereby suggesting this may be an offtarget. Due to the relatively high doses that may be encountered clinically with AR-NTD inhibitors, identification of off-targets may provide insight into potential adverse events, contraindications, or poor efficacy.

Keywords: prostate cancer; metallothionein; androgen receptor; ralaniten; off-target; sintokamide; MTF1 


\section{Introduction}

Between 20 and $30 \%$ of patients with localized prostate cancer will experience recurrence and require systemic therapy. Androgen deprivation therapy (ADT) remains the first-line treatment; however, patients with metastatic disease will inevitably progress to castration-resistant prostate cancer (CRPC) despite initial response [1]. Following surgical or chemical castration, CRPC is clinically defined by an increase in the levels of serum prostate-specific antigen (PSA) which is an androgen receptor (AR)-regulated gene. These rises in serum PSA imply that the disease is still driven by AR transcriptional activity [2-4]. Second-generation hormonal therapies such as enzalutamide or abiraterone both directly or indirectly inhibit AR transcriptional activity by targeting the AR C-terminal ligand-binding domain (LBD) [5,6]. While initially effective, resistance to these therapeutics ultimately arises generally within 12-24 months [2,7]. Multiple mechanisms of resistance exist that continue to exploit the AR signaling pathway. These mechanisms include: amplification of the AR gene [8] and increased AR expression [9]; the emergence of AR-LBD mutations [10,11]; constitutively active AR splice variants (AR-Vs), which lack the LBD [12,13]; and de novo intratumoral androgen synthesis [7]. Unlike the AR-LBD, the N-terminal domain (NTD) is essential for transcriptional activities of both full-length AR and ARVs $[14,15]$. Preclinical studies demonstrating the utility of the first small-molecule inhibitors (ralaniten/EPI-002 and sintokamide/SINT1) designed to specifically target the AR-NTD have been described [16,17]. These inhibitors have shown success in the context of AR-Vs, AR gain-of-function mutations [17,18], amplified AR, altered AR NTD polyglutamine tract length, elevated levels of AR coactivators, and elevated levels of androgen [18,19]. In following, the prodrug of ralaniten (ralaniten acetate or EPI-506) and the second-generation EPI-7386 remain the first and only small-molecule inhibitors to have entered into Phase I clinical trials (Ralaniten, NCT02606123; EPI-7386, NCT04421222). Ralaniten acetate was well tolerated in heavily pretreated CRPC patients and imparted PSA responses and stable disease in some patients; however, it failed to advance to Phase II due to a poor pharmacokinetic profile. This proof of concept for the chemical structure and mechanism of action resulted in the development of more potent analogues with improved druglike qualities and metabolic stability. Thus, small molecules targeting the AR-NTD have a therapeutic niche, especially in the post-enzalutamide or -abiraterone setting [18-20]. Research and development of alternative compounds with improved potency, as well as combination therapies with EPI compounds, are ongoing [21-24], and a clinical trial investigating the combination of EPI-7386 with enzalutamide has begun (NCT05075577).

AR functions as a master regulator of thousands of genes and directly influences a myriad of cellular responses. Compounds that target the AR-NTD versus the AR-LBD have a markedly different mechanism of action, and potentially disrupt different downstream cellular pathways. Indeed, differences between ralaniten and SINT1 have been shown despite both targeting the AF-1 region within the AR-NTD [17]. Here, we begin to describe the molecular profile of ralaniten in an effort to better understand how AR-NTD inhibitors disrupt the molecular pathways under the control of the AR, and how this differs from existing AR-LBD inhibitors. In doing so, we aimed to discern whether the effects of ralaniten were specific to that compound, or were inherent to AR-NTD inhibitors as a whole. We found that both AR-LBD inhibitors and AR-NTD inhibitors were effective at preventing the induction of genes upregulated by the AR in response to androgen. Interestingly, differences between the two classes of inhibitors were much more apparent with respect to the ability to de-repress expression of androgen-repressed genes. Importantly, these studies led to the discovery of the unique induction of expression of metallothionein genes with ralaniten treatment. This unexpected result was not replicated with other AR-NTD inhibitors, and appeared to involve a mechanism that was independent of AR.

Metallothioneins are small $(\sim 6 \mathrm{kDa})$ cysteine-rich proteins that are capable of binding numerous essential as well as toxic metal ions; however, they preferentially form complexes with zinc $[25,26]$. Metallothioneins are ubiquitously expressed and play important roles in metal ion homeostasis and detoxification, as well as in protecting the cell from oxidative 
stress [27]. Metal response elements (MREs) have been defined in the proximal promoter elements of metallothionein members of the MT1 and MT2 subfamilies. Transcription of these genes is markedly enhanced following exposure to zinc and cadmium, primarily through the action of metal regulatory transcription factor 1 (MTF-1) binding to the MRE [28]. Since metallothioneins play a pivotal role in carcinogenesis and drug resistance [29], identifying the mechanism by which ralaniten increased their expression was of substantial interest.

\section{Results and Discussion}

\subsection{Ralaniten Has a Unique Molecular Signature}

To better understand the mechanism of action of ralaniten, and to identify differences between LBD antagonists, we performed a whole transcriptome microarray on cDNA isolated from LNCaP cells (Figure 1A), a model for which much of the preclinical work in developing ralaniten was performed, as well as decades of studies on androgen-regulated genes [16,19,30-32]. Cells were treated with enzalutamide $(5 \mu \mathrm{M})$, bicalutamide $(10 \mu \mathrm{M})$, ralaniten $(35 \mu \mathrm{M})$, or DMSO vehicle and stimulated with 1nM R1881. We began by defining an androgen-responsive gene set. Protein-coding genes that were either induced $(n=456)$ or repressed $(n=209) \geq 2$-fold following stimulation with synthetic androgen R1881 were identified. Of these genes, the ability of each inhibitor to attenuate expression in the induced gene set, or de-repress expression in the repressed gene set by $\geq 2$-fold was determined (Figure 1B,C). There was a large amount of overlap between all three inhibitors for attenuating the expression of androgen-induced genes. Closer inspection of the genes most induced by androgen revealed that all three compounds were capable of significantly reducing their expression (Figure 1D). Conversely, there was a much lower degree of commonality when we examined androgen-repressed genes. In this case, while bicalutamide and enzalutamide appeared to behave similarly with respect to specific genes each was able to de-repress, ralaniten had a unique signature. Furthermore, ralaniten had little effect on de-repressing the expression of the genes that were most susceptible to repression by androgen (Figure 1E). Both bicalutamide and enzalutamide were substantially superior in this regard compared to ralaniten. These data revealed for the first time the differences between AR-LBD inhibitors and AR-NTD inhibitors in gene expression. The differential impact between these two classes of inhibitors was most prominent with respect to disrupting the AR to de-repress androgen-repressed gene expression, which supported the role of specific AR domains in the multiple and complex mechanisms known to mediate transcriptional repression (for a review, see Grosse et al. 2012 [33]).

To determine what changes in gene expression were uniquely and significantly elevated in ralaniten-treated samples, hierarchical clustering was employed (Figure 1A). Unexpectedly, 5 of the top 11 genes that were positively associated with ralaniten-treatment were members of the metallothionein family (MT1F, MT2A, MT1G, MT1H, MT1X). Relative expression ranged from 6.52- to 18.40 -fold over $\mathrm{DMSO}$ vehicle control $\left(\mathrm{Log}_{2} \mathrm{FC}=2.711-4.125\right.$; Figure $1 \mathrm{~F}$ ), and notably, this effect did not occur with bicalutamide or enzalutamide. A subsequent GSEA was performed on the array data (Figure 1G-J) to obtain deeper insight into differences between the classes of AR inhibitors. As expected, the top gene set enriched in samples treated with androgen compared to DMSO vehicle control involved the androgen response (NELSON_RESPONSE_TO_ANDROGEN_UP, FDR =0.000), and also as expected, all inhibitors had an overall negative expression pattern with genes in this set (Figure $1 \mathrm{G}$ ). However, as seen in the earlier analysis (Figure 1C,E), ralaniten was unable to de-repress the expression of androgen-repressed genes (NELSON_RESPONSE_TO_ANDROGEN_DN, FDR $=0.000$, Figure $1 \mathrm{H})$. Furthermore, ralaniten was strongly associated with the increased expression of MT1 and MT2 genes (REACTOME_RESPONSE_TO_METAL_IONS, FDR $=0.000$, Figure 1I; and REACTOME_METALLOTHIONEINS_BIND_METALS, FDR $=0.001$, Figure $1 \mathrm{~J}$ ). Collectively, these data revealed that ralaniten: (1) was relatively poor at de-repressing the expression of androgen-repressed genes compared to bicalutamide and enzalutamide; and (2) uniquely induced the expression of genes within the metallothionein family. 


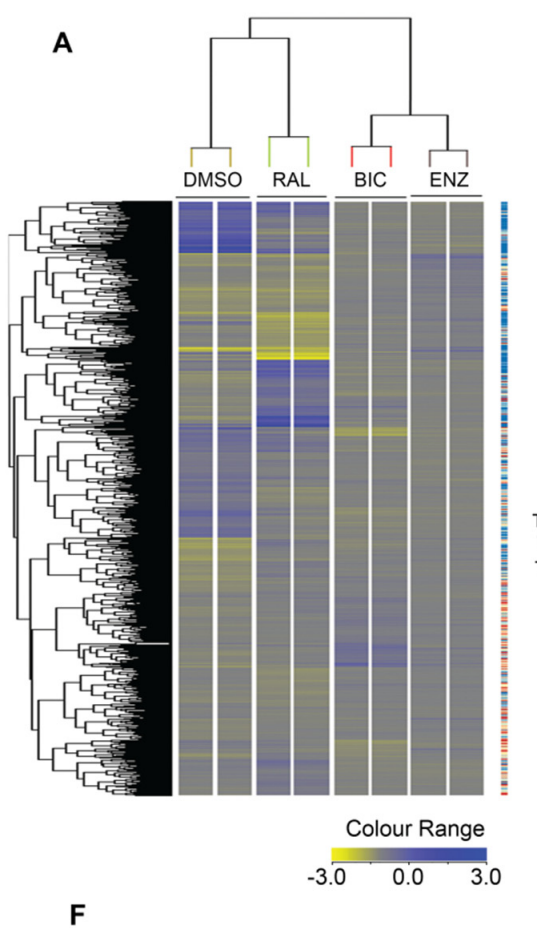

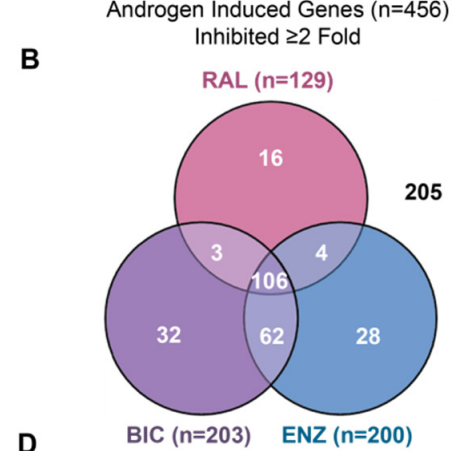

Top Androgen Induced Genes

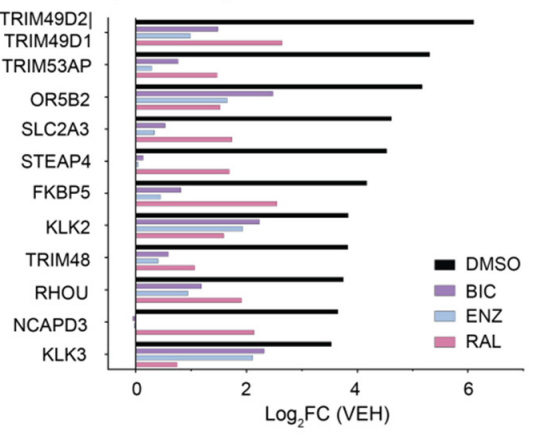

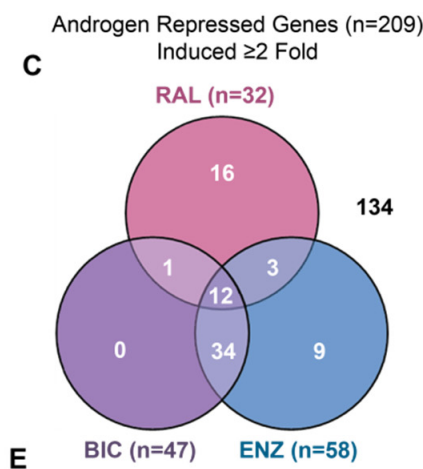

Top Androgen Repressed Genes

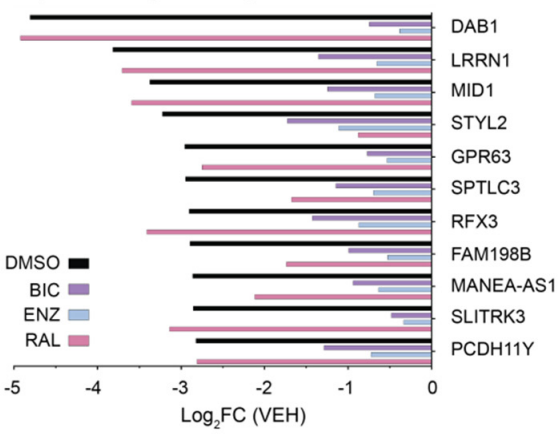

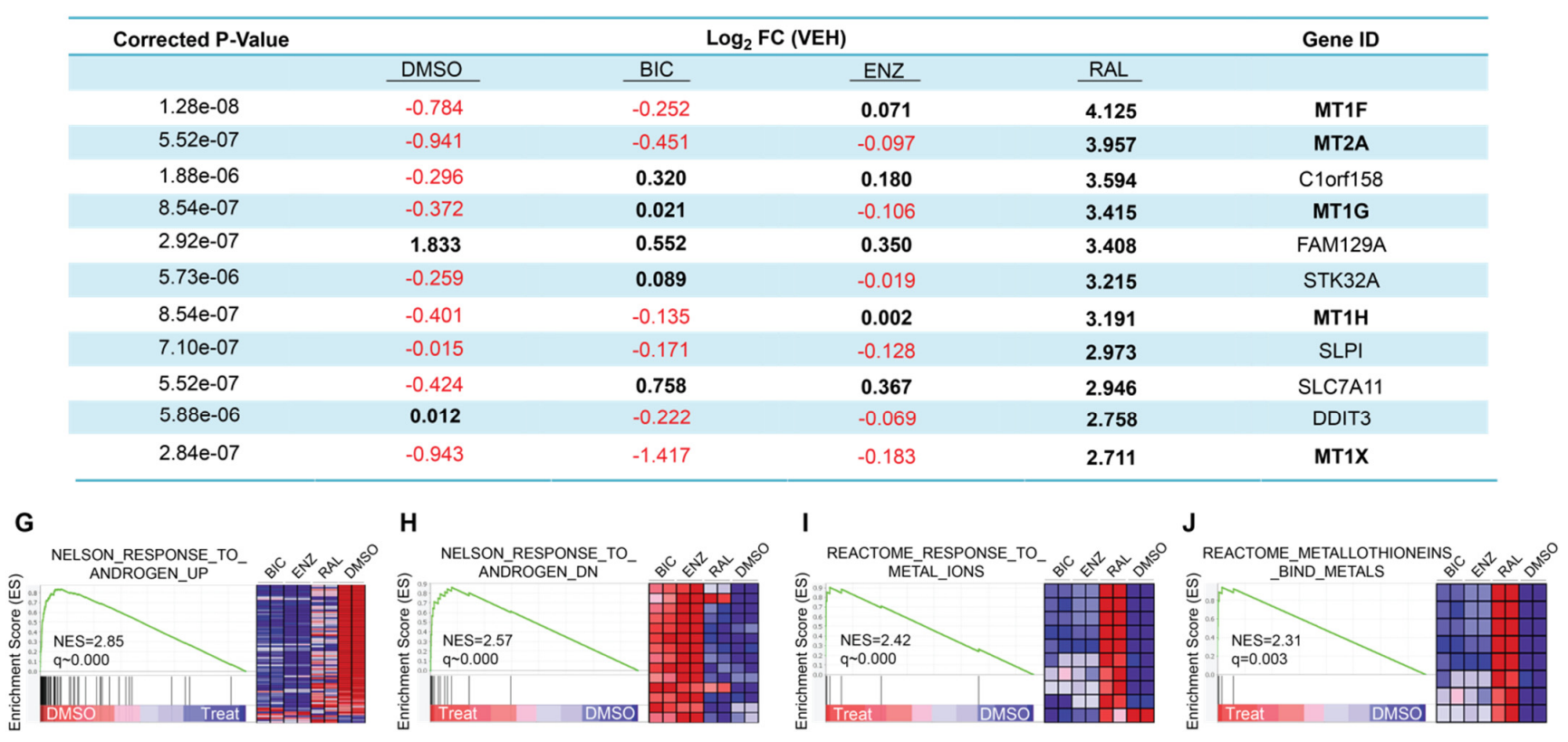

Figure 1. Differential gene expression profiles between AR-LBD inhibitors and an AR-NTD inhibitor. (A) Heatmap showing differentially regulated genes following treatment with bicalutamide $(10 \mu \mathrm{M})$, enzalutamide $(5 \mu \mathrm{M})$, ralaniten $(35 \mu \mathrm{M})$, or DMSO vehicle (R1881 only), and all stimulated with $1 \mathrm{nM}$ R1881 for $24 \mathrm{~h}$. Data were normalized to vehicle treated with EtOH (no R1881). Analysis of global gene expression identified androgen-regulated genes that were specifically induced $(n=456)$ (B) or repressed $(n=209)$ (C). The Venn diagrams show the numbers of androgen-regulated genes in these subsets whose expression decreased/increased by $\geq 2$-fold in the presence of bicalutamide, enzalutamide, or ralaniten. Numbers outside Venn diagrams indicate genes that were not affected by any drug treatment. Top androgen-induced (D) and -repressed (E) genes ranked by fold-change normalized to DMSO/EtOH (no R1881). LNCaP cells were incubated with enzalutamide (ENZ, $5 \mu \mathrm{M}$ ), bicalutamide (BIC, $10 \mu \mathrm{M}$ ), ralaniten (Ral, $35 \mu \mathrm{M}$ ), or DMSO vehicle (with and without $1 \mathrm{nM}$ R1881). All drug treatments were stimulated with $1 \mathrm{nM} \mathrm{R} 1881$ for $24 \mathrm{~h}$ before harvesting and isolation 
of RNA for analyses. (F) Table showing the top genes that positively correlated with ralaniten treatment. Normalized expression values which are reduced compared to vehicle control are indicated in red, expression values which are increased, are in bold. Five genes clustered within the metallothionein family showed significant enrichment, and were specifically associated with ralaniten treatment. (G) GSEA plot of top gene set that showed enrichment in DMSO control (R1881 only) compared against drug treatment. (H-J) GSEA plots of top gene sets that showed enrichment in drug-treated samples compared to DMSO control (R1881 only). Associated heatmaps show expression patterns of core enriched genes for each treatment. Ralaniten had a unique signature, while bicalutamide and enzalutamide had similar expression patterns. All data were normalized to DMSO control in the absence of R1881 (EtOH). DMSO means R1881 treatment only. Bicalutamide, enzalutamide, and ralaniten were all in the presence of R1881.

\subsection{Induction of Metallothioneins Is Specific to Ralaniten}

To determine if the induction of metallothionein isoforms was specific to ralaniten or common to inhibitors of the AR-NTD, we employed a second-generation ralaniten analogue (EPI-7170) and two sintokamide analogues (SINT1 and LPY-26), which are structurally and mechanistically unique (Figure 2A,B). Sintokamide A (SINT1/compound 1; Figure 2B) is a natural compound that binds the AR AF1 region N-terminal to the binding site of ralaniten [17]. Functionally, SINT1 does not block STAT3 interaction with the AR-NTD, and consequently, it fails to block IL-6 transactivation of the AR-NTD, making it unique from ralaniten [16]. LPY-26 (compound 2) is a synthetic form of SINT1, and is presumed to bind in the same region as SINT1. EPI-7170 (compound 3) is a more potent analogue of ralaniten (compound 4) [22]. BADGE- $2 \mathrm{H}_{2} \mathrm{O}$ (compound 5) has a high degree of structural similarity to ralaniten, yet does not bind $A R$ and has no antagonistic effect against the AR [16], and was included as a control. Enzalutamide (compound 6) has no structural similarity to the NTD inhibitors, and targets the AR-LBD.

We first compared the AR-NTD inhibitors that bind to unique regions in the NTD to determine if the induction of expression of metallothionein genes was specific to ralaniten or common to NTD inhibitors. LNCaP human prostate cancer cells were transfected with luciferase reporter constructs fused to the promoter regions of metallothionein isoforms (MT1F, MT2, MT1G) found to be upregulated in the array data, and treated with $35 \mu \mathrm{M}$ of each compound. Only ralaniten induced these metallothionein reporters (Figure 2C), suggesting that this effect was unique to ralaniten and not common to all NTD inhibitors. Consistent with the trends generated for the metallothionein reporter gene constructs, ralaniten also uniquely induced expression of endogenous metallothionein genes as determined by employing RT-PCR to measure levels of mRNA transcripts. Ralaniten significantly increased levels of expression of MT1F, MT1G, MT1X, and MT2A, whereas the more potent analogue EPI-7170 and the AR-LBD inhibitor enzalutamide did not (Figure 2D).

To confirm if induction of metallothionein genes by ralaniten occurred in vivo, castrated mice bearing LNCaP xenografts were randomized into three treatment groups: ralaniten $(233 \mathrm{mg} / \mathrm{kg})$, EPI-7170 $(56.6 \mathrm{mg} / \mathrm{kg})$, or vehicle control (CMC). Consistent with previous reports [21,22], both ralaniten and EPI-7170 were highly effective at preventing growth of these CRPC xenografts (Figure 2E), and had no significant impact on the body weights of animals (Figure 2F). Analyses of levels of expression of metallothionein genes from harvested xenografts were consistent with the in vitro data. Levels of expression of MT1F, MT1X, and MT2A were all significantly increased in xenografts harvested from animals dosed with ralaniten (Figure 2G). Interesting, EPI-7170 did increase expression of MT1F mRNA slightly but significantly compared to the vehicle control (CMC), but had no significant effect on levels of MT1X, MT1G, or MT2A. 
A

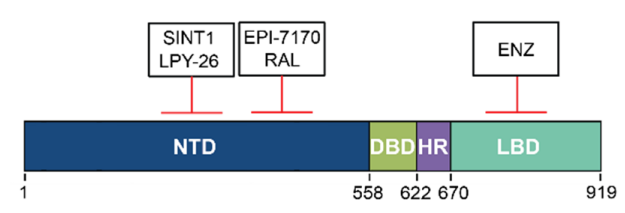

C
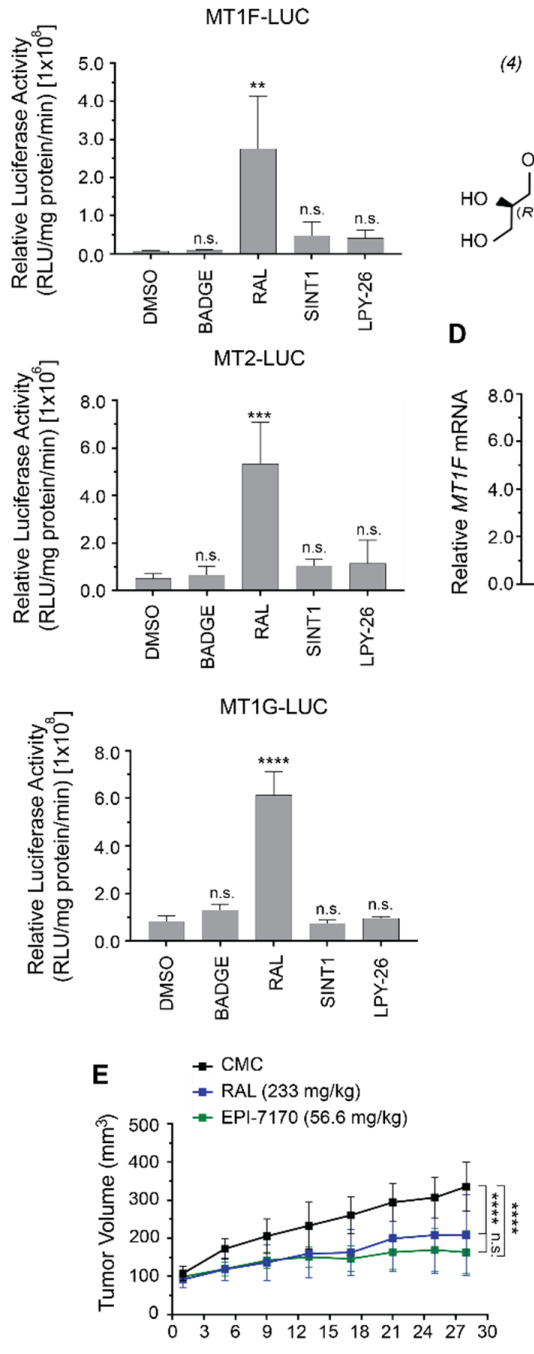

Days after 1st Treatment

$$
\text { F }
$$

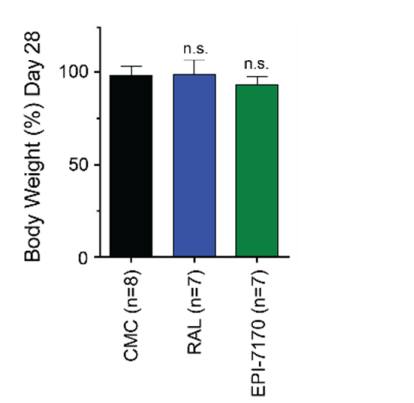

B (1)

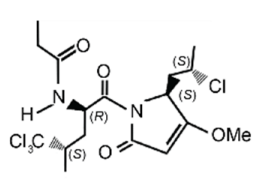

SINT1

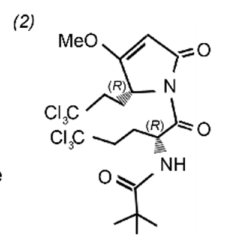

LPY-26<smiles>CNCC(O)Oc1ccc(C(C)(C)c2cc(Cl)c(OC[C@H](O)CCl)c(Cl)c2)cc1</smiles>

EPI-7170<smiles>[R10]CN=C(N)N=N</smiles>
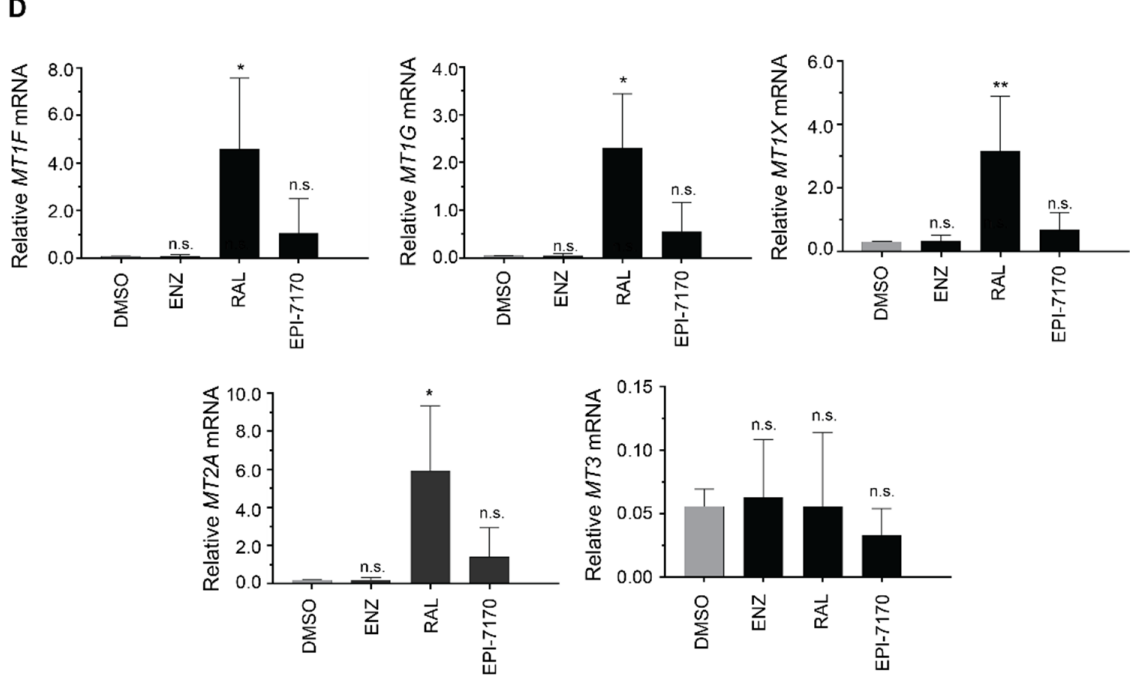

G
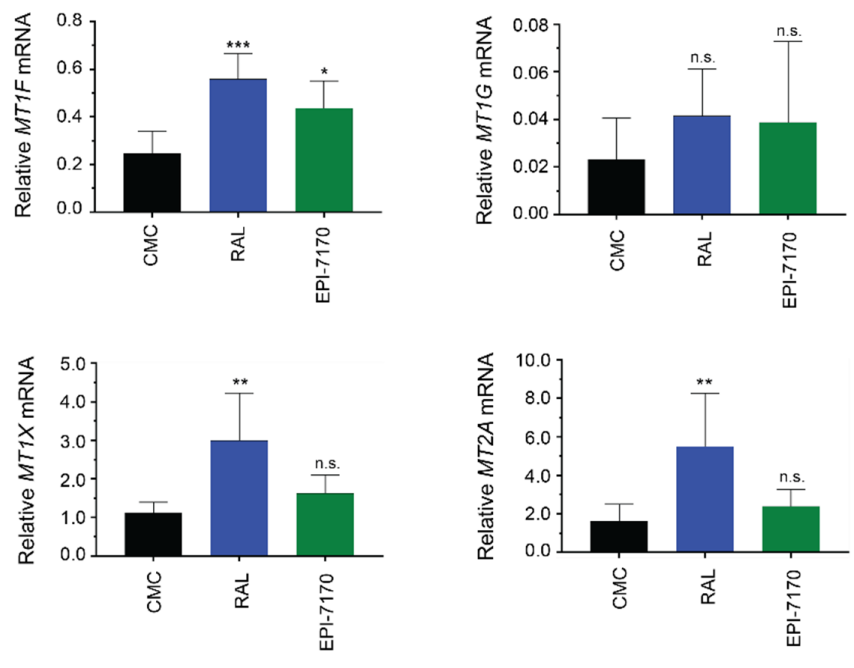

Figure 2. Ralaniten-induced expression of metallothionein in vitro and in vivo. (A) Illustration depicting the various compounds tested with respect to which region they bind on AR. (B) Chemical structure of each compound. BADGE- $2 \mathrm{H}_{2} \mathrm{O}$ does not bind $\mathrm{AR}$ and has no inhibitory effect on AR transcriptional activity. (C) LNCaP cells transfected with the various MT1/2-luciferase reporters and treated with DMSO, BADGE-2 $\mathrm{H}_{2} \mathrm{O}(35 \mu \mathrm{M})$, ralaniten $(35 \mu \mathrm{M})$, SINT1 $(35 \mu \mathrm{M})$, or LPY-26 $(35 \mu \mathrm{M})$ for $24 \mathrm{~h}$. Data presented as mean $\pm \mathrm{SD}$ and analyzed by one-way ANOVA with Dunnett's test applied 
post hoc ( $n=3$ independent experiments). (D) Transcript levels of MT1F, MT1G, MT1X, MT2A, and MT3 normalized to SDHA from LNCaP cells treated with enzalutamide $(5 \mu \mathrm{M})$, ralaniten $(35 \mu \mathrm{M})$, EPI-7170 $(5 \mu \mathrm{M})$, or $v / v$ DMSO. Data presented as mean \pm SD and analyzed by two-way ANOVA with Sidak's test applied post hoc ( $n=3$ independent experiments). (E) Ralaniten and EPI-7170 inhibited the growth of LNCaP CRPC xenografts in castrated hosts. One week after castration, when tumors were approximately $100 \mathrm{~mm}^{3}$, animals were dosed daily by gavage with CMC vehicle (3\% DMSO, 1.5\% Tween 80, 1\% CMC), Ral (233 mg/ $\mathrm{kg}$ body weight), or EPI-7170 (56.6 mg/ $\mathrm{kg}$ body weight). Mean $\pm \mathrm{SD}$ of $n=9$ or 10 for each group. (F) Body-weight change over the course of the experiment. Data presented as mean \pm SD and analyzed by two-way ANOVA with Dunnett's test applied post hoc ( $n=8$ or 7 mice per group). (G) Real-time PCR for measurement of levels of MT1F, MT1G, MT1X, and MT2A transcripts that were normalized to levels of SDHA transcript using RNA harvested from LNCaP xenografts $(n=6, \mathrm{CMC} ; n=4, \mathrm{RAL} ; n=7, \mathrm{EPI}-7170) .{ }^{*} p<0.05 ;{ }^{* *} p<0.01$; ${ }^{* * *} p<0.001 ; * * * * 0.0001 ;$ n.s., not significant. ENZ, enzalutamide, RAL, ralaniten.

\subsection{Dose-Dependent Induction of Metallothionein by Ralaniten}

To determine whether the induction of metallothionein expression was dependent upon concentration of ralaniten, MT1F and MT2 reporter gene constructs were transiently transfected into LNCaP cells. A dose-dependent response was observed, with significant induction occurring at $25 \mu \mathrm{M}$ concentrations of ralaniten for both reporters (Figure 3A). Our next aim was to discover whether the induction of metallothionein expression by ralaniten was restricted to $\mathrm{LNCaP}$ cells, or could be replicated in additional models. To this end, LNCaP95 (LN95) cells were utilized. Despite expressing functional full-length AR (AR-FL), these cells are reliant upon the splice variant AR-V7 to drive proliferation. Therefore, the dose dependence of ralaniten on induction of endogenous expression of metallothionein genes was also measured in LNCaP and LN95 cells. Ralaniten strongly induced expression of metallothionein isoforms in a dose-dependent response in both of these cell lines, demonstrating that the induction of metallothionein expression by ralaniten was not specific to LNCaP cells. This effect was not measured with any concentration of enzalutamide (Figure 3B). Interestingly, EPI-7170 had a similar effect, but only at the highest concentration tested $(20 \mu \mathrm{M})$ in LN95 cells (Figure 3C). EPI-7170 at $20 \mu \mathrm{M}$ was cytotoxic in LNCaP cells.

\subsection{Induction of Metallothionein Isoforms by Ralaniten Is not Dependent upon the AR}

Expression of metallothionein genes are regulated through a number of response elements within its regulatory regions. These include binding sites for glucocorticoid receptor (GR), NRF2, and MTF-1 [28,34,35], which were within the metallothionein reporter gene constructs employed here (for a review, see Coyle et al. 2002 [35]). Since AR and GR can overlap in binding some shared-response elements on genes [36,37], we next determined if AR played a role in the induction of metallothionein genes by ralaniten. To do this, we first determined if expression of AR was required for ralaniten induction of expression of metallothionein genes. Metallothionein gene expression was assayed in several additional prostate cancer cell lines that lack AR expression (DU145) or express very low levels of nonfunctional AR (PC3). Both the LNCaP and LN95 cell lines were included, as they each had demonstrated increased metallothionein expression in response to ralaniten treatment previously (Figure 3B). Overall, LN95 cells behaved similarly to LNCaP cells that only express full-length AR, with ralaniten significantly inducing metallothionein expression (Supplementary Figure S1A). Conversely, neither DU145 nor PC3 cells demonstrated any statistically significant induction of expression of metallothionein following ralaniten treatment (Supplementary Figure S1B,C). As seen previously in LNCaP cells, both enzalutamide and EPI-7170 also failed to induce expression of metallothionein in any cell line. Collectively, these data implied that the ability of ralaniten to induce expression of metallothionein genes may be reliant upon functional full-length AR, or alternatively, may be cell-specific. 
A
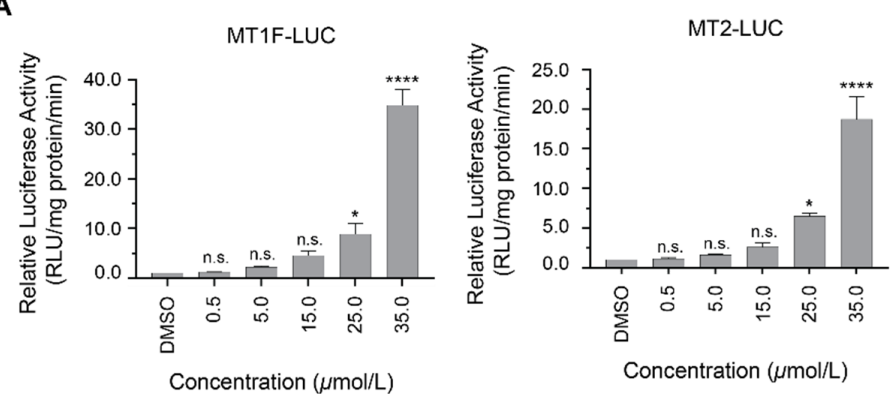

B

LNCaP
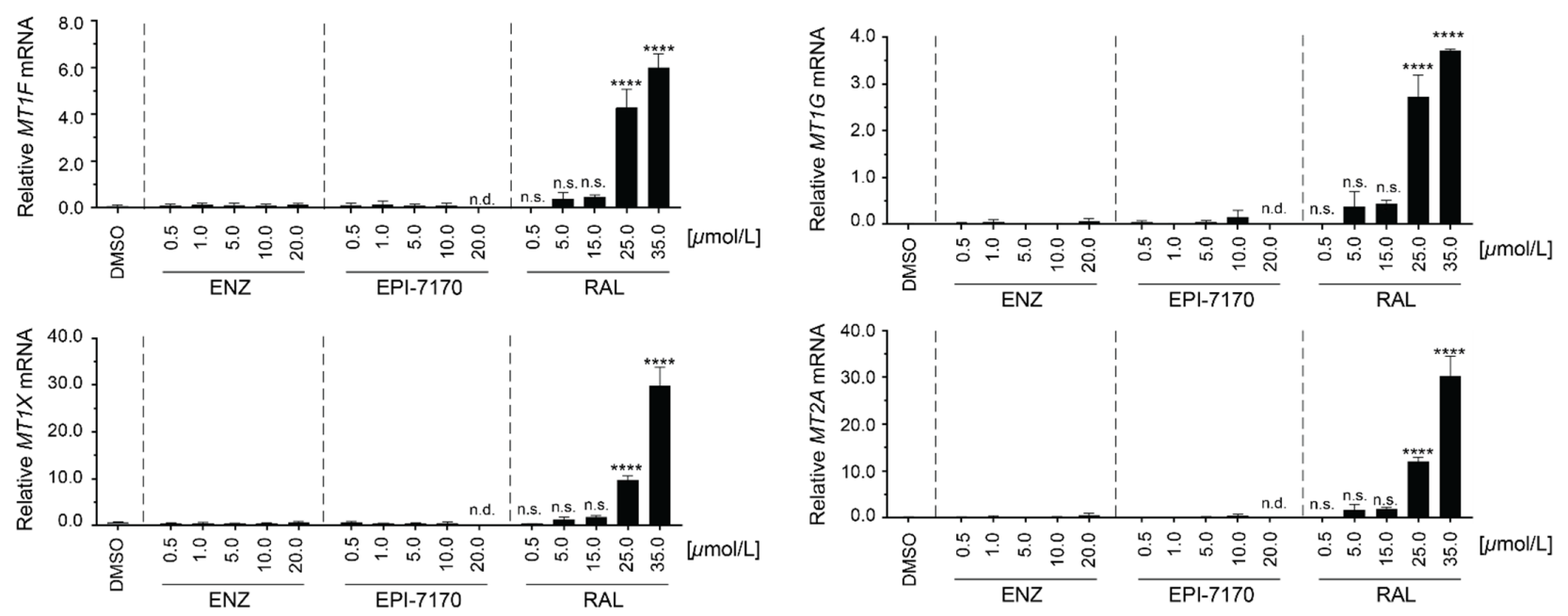

C

LN95
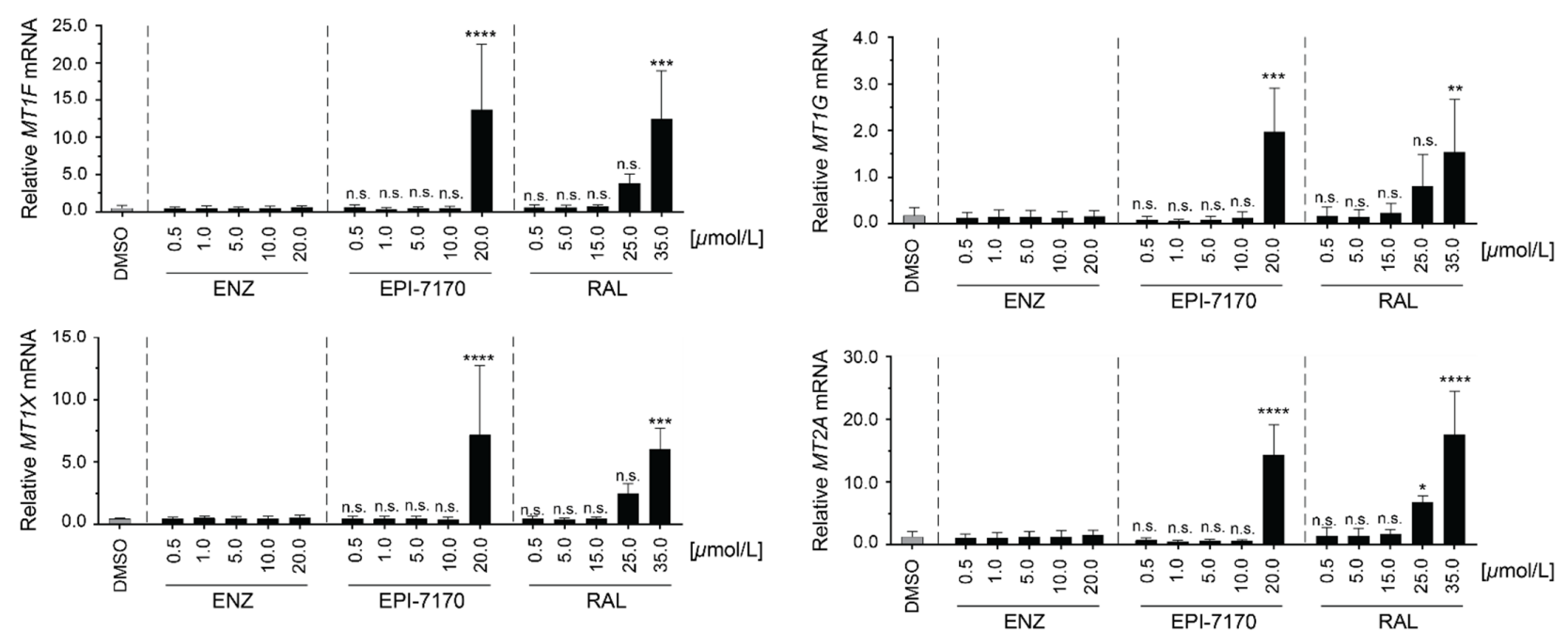

Figure 3. Induction of metallothionein gene expression by ralaniten is dependent on concentration. (A) LNCaP cells were transiently transfected with MT1-luciferase or MT-2-luciferase reporters. Cells were subsequently treated with DMSO or increasing concentrations of ralaniten $(0.5-35 \mu \mathrm{M})$ for $24 \mathrm{~h}$. (B) LNCaP and (C) LN95 transcript levels of MT1F, MT1G, MT1X, and MT2A normalized to levels of SDHA transcript from cells treated with DMSO, or increasing concentrations of enzalutamide, EPI-7170, and ralaniten for $24 \mathrm{~h}$. Data presented as mean \pm SD and analyzed by two-way ANOVA with Dunnet's test applied post hoc ( $n=3$ independent experiments). EPI-7170 was toxic at $20 \mu \mathrm{M}$ in $\mathrm{LNCaP}$ cells. ${ }^{*} p<0.05 ;{ }^{* *} p<0.01 ;{ }^{* * *} p<0.001$; ${ }^{* * *} p<0.0001$; n.s., not significant. ENZ, enzalutamide; RAL, ralaniten; n.d., not detected. 
To more definitively address the requirement for $\mathrm{AR}$ in the mechanism of induction of metallothionein isoforms by ralaniten, levels of AR were knocked down in LNCaP and LN95 cells, and subsequently treated with DMSO vehicle (in the presence and absence of androgen), enzalutamide $(5 \mu \mathrm{M})$, ralaniten $(35 \mu \mathrm{M})$, or EPI-7170 $(5 \mu \mathrm{M})$, all in the absence of androgen stimulation. While AR protein levels were robustly silenced after $24 \mathrm{~h}$ in LNCaP cells (Figure 4A), the effect was lessened in LN95 cells (Figure 4B and Supplementary Figure S2 for uncut gels). Nonetheless, treatment with AR siRNA alone was sufficient to reduce expression of canonical AR-regulated genes (KLK3/PSA and FKBP5) in the presence of synthetic androgen R1881 in both cell lines, supporting a reduction in AR-FL (Figure $4 C, D$ ). Ralaniten retained the ability to induce expression of metallothionein, despite the loss of AR levels and subsequent activity in both cell lines (Figure 4E,F). There was little to no decrease in mRNA expression levels of any metallothionein isoform induced with ralaniten with AR knockdown. Collectively, these data supported that ralaniten-induced expression of metallothionein was independent of AR, and suggested that this induction may be an off-target of ralaniten.

\subsection{Induction of Metallothionein Isoforms by Ralaniten Is Not Associated with NRF2 Expression or Increased Oxidative Stress}

The genes for metallothionein contain antioxidant response elements (ARE) to which NRF2 binds to increase levels of expression in response to oxidative stress [34,38,39]. Both ralaniten and EPI-7170 increased levels of NRF2 protein in LNCaP and LN95 cells (Supplementary Figure S3A,B, and Supplementary Figure S4 for uncut gels). In agreement with increased levels of NRF2 protein, ralaniten and EPI-7170 also induced levels of canonical NRF2-regulated genes, NQO1 and SLC11A7, which could be blocked by knockdown of NRF2 (Supplementary Figure S3C,D). Importantly, knockdown of NRF2 did not reduce ralaniten-induced expression of metallothionein in either LNCaP or LN95 cells (Supplementary Figure S3E,F). These data indicate that ralaniten induction of metallothionein was driven by a mechanism independent of NRF2.

Oxidative stress has been shown to lead to zinc disassociation from metallothionein proteins, which could also lead to an increase in free zinc ions to activate MTF-1 independently of NRF2 [28]. To test this, the fluorescent probes MitoSOX and 2',7'-dichlorofluorescin diacetate (DCFDA) were used to detect production of intracellular ROS following treatment with ralaniten, EPI-7170, enzalutamide, and the positive control, tert-butyl hydroperoxide (tBHP). Neither enzalutamide nor the AR-NTD inhibitors mediated a positive signal for mitoSOX (Supplementary Figure S5A), whereas a modest yet significant increase in ROS was seen only for enzalutamide compared to DMSO control, and only in LNCaP cells (Supplementary Figure S5B). Neither ralaniten nor EPI-7170 mediated any increase in ROS generation (Supplementary Figure S5A,B).

\subsection{Induction of Metallothionein Isoforms by Ralaniten Is Dependent upon MTF1}

Transcription of metallothionein subfamilies MT1 and MT2 is markedly enhanced through MTF-1 binding to MREs within their proximal promoters [28]. The transcriptional activity of MTF-1 is regulated by nuclear localization and a metal-responsive transactivation domain $[27,28,34]$. To determine the role of MTF-1 in the mechanism of induction of metallothionein by ralaniten, levels of this transcription factor were measured in response to increasing concentrations of ralaniten and in the context of knockdown of MTF-1 in LNCaP (Figure 5A) and LN95 cells (Figure 5B). In LNCaP cells, both androgen and ralaniten slightly elevated levels of expression of MTF-1, although this was not significant (Figure 5A). Interestingly in LN95 cells, ralaniten at $35 \mu \mathrm{M}$ approximately doubled the levels of expression of MTF-1, an effect that was more pronounced in the sample treated with control siRNA (Figure 5B). Regardless, knockdown of MTF-1 significantly blocked ralaniten induction of expression of metallothionein isoforms (MT1F, MT1X, MT2A) in both cell lines (Figure 5A,B). These data suggested that ralaniten-induced expression of metallothionein was dependent upon expression levels of MTF-1. 
A

$\mathrm{LNCaP}$

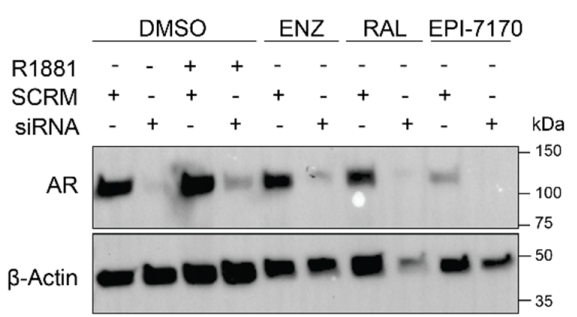

C
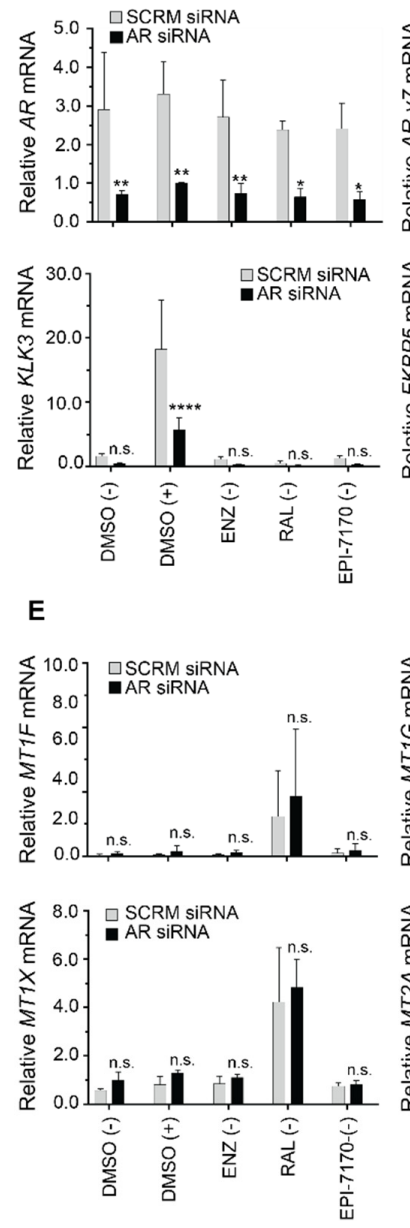
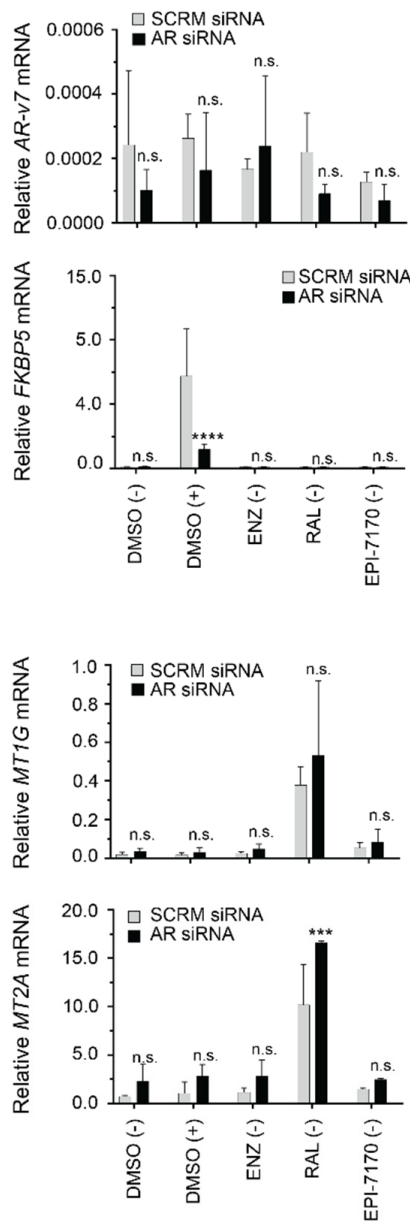

B LN95

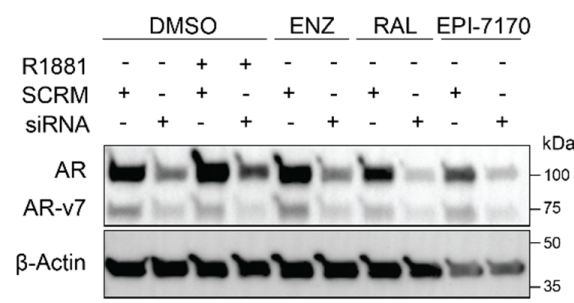

D
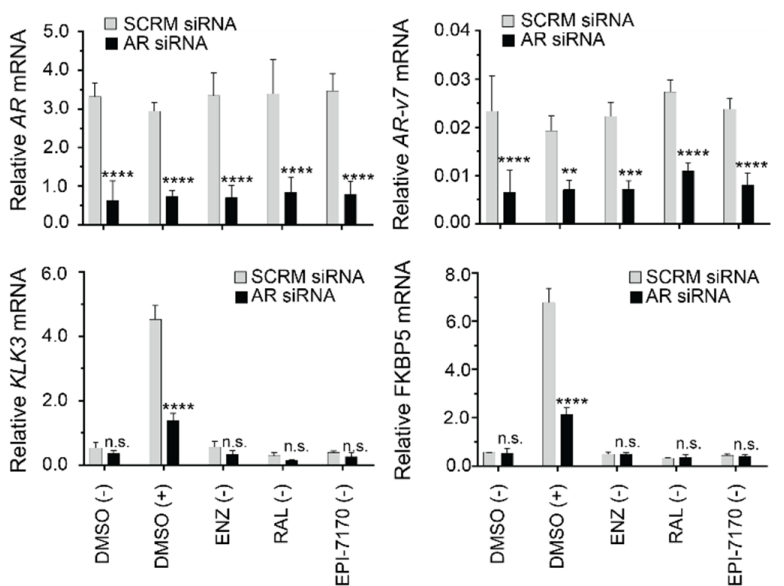

F
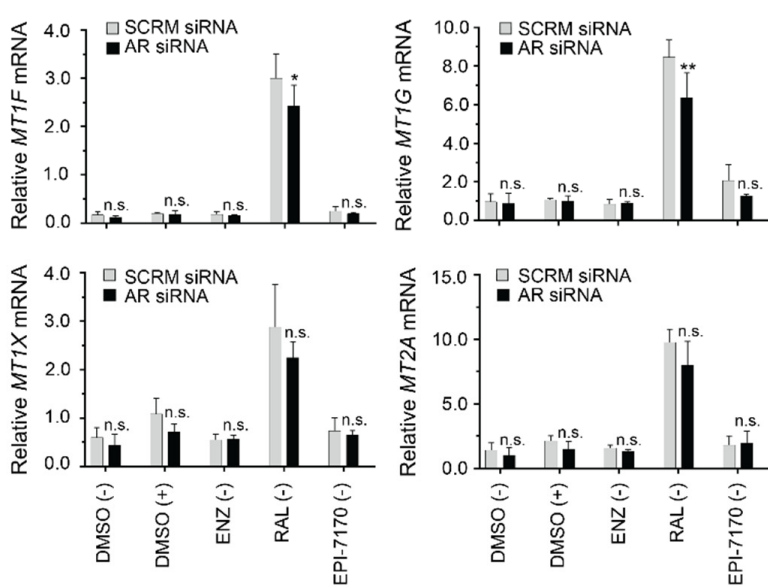

Figure 4. Ralaniten-induced expression of metallothionein is independent of levels of AR. (A) Western blot analyses of levels of AR proteins in LNCaP and (B) LN95 cells transfected with scramble (SCRM, control) or AR siRNA $(10 \mathrm{nM})$ for $24 \mathrm{~h}$ and treated with DMSO, enzalutamide $(5 \mu \mathrm{M})$, ralaniten $(35 \mu \mathrm{M})$, or EPI-7170 $(5 \mu \mathrm{M})$ in the presence or absence of $1 \mathrm{nM}$ R1881. The uncropped immunoblot images can be found in Figure S2. (C) Transcript levels of AR, AR-V7, KLK3, and FKBP5 were normalized to transcript levels of SDHA from LNCaP and (D) LN95 cells treated with DMSO, enzalutamide $(5 \mu \mathrm{M})$, ralaniten $(35 \mu \mathrm{M})$, or EPI-7170 $(5 \mu \mathrm{M})$ in the presence $(+)$ or absence $(-)$ of $1 \mathrm{nM}$ R1881. (E) Transcript levels of MT1F, MT1G, MT1X, and MT2A were normalized to transcript levels of SDHA from LNCaP and (F) LN95 cells treated with DMSO, enzalutamide $(5 \mu \mathrm{M})$, ralaniten $(35 \mu \mathrm{M})$, or EPI-7170 $(5 \mu \mathrm{M})$ in the presence (+) or absence (-) of $1 \mathrm{nM}$ R1881. Ralaniten induction of expression of metallothionein isoforms was generally not reduced or only modestly impacted by knockdown of AR. Data presented as mean \pm SD and analyzed by two-way ANOVA with Sidak's test applied post hoc ( $n=3$ independent experiments). ${ }^{*} p<0.05 ;{ }^{* *} p<0.01 ;{ }^{* * *} p<0.001$; ${ }^{* * * *} p<0.0001$; n.s., not significant. ENZ, enzalutamide; RAL, ralaniten; +, R1881; - , EtOH. 

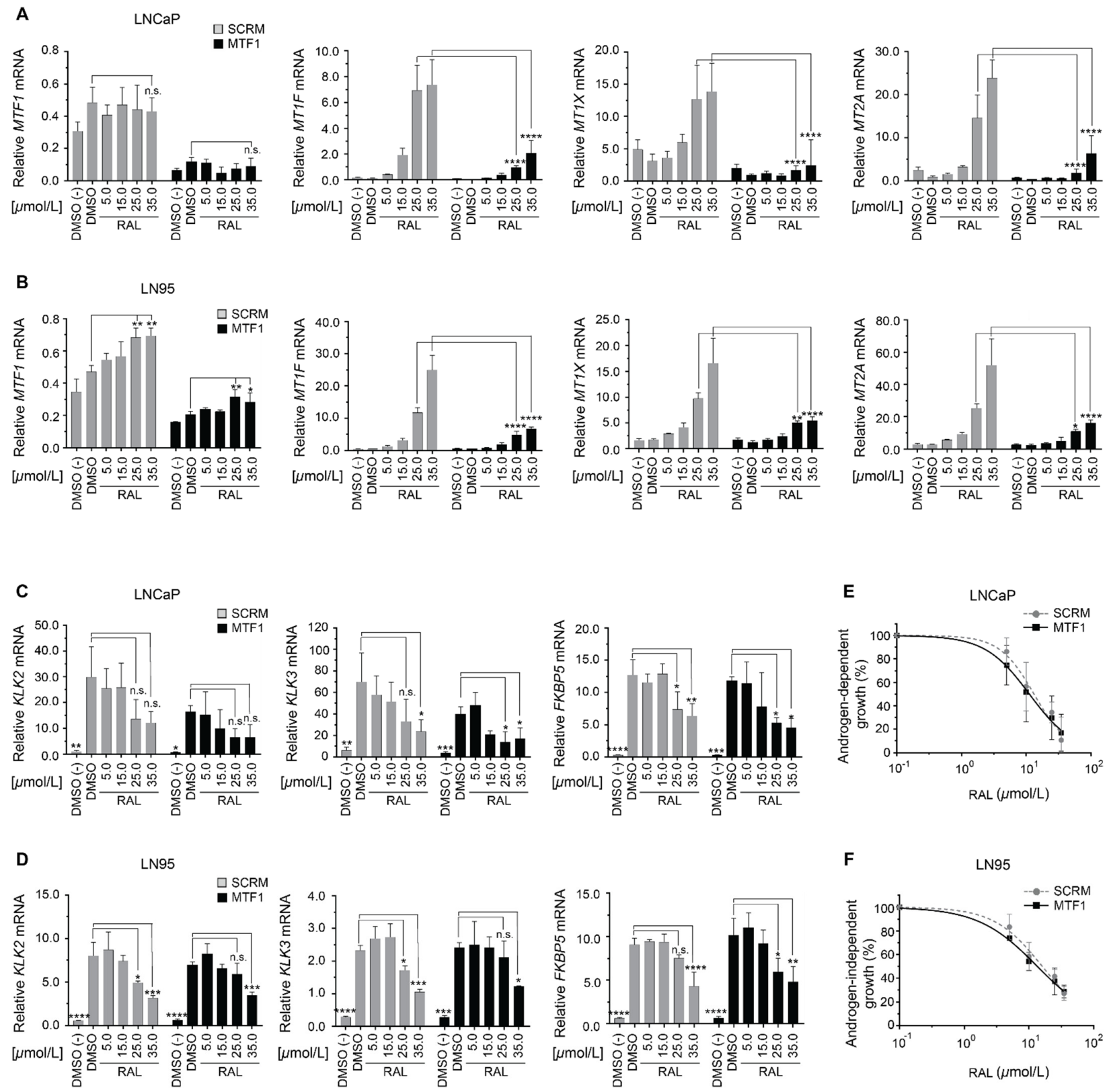

Figure 5. Ralaniten-induced expression of metallothionein is dependent on levels of MTF-1. (A) Transcript levels of MTF-1, MT1F, MT1X, and MT2A were normalized to transcript levels of SDHA from LNCaP and (B) LN95 cells treated with siRNA targeting MTF-1 followed by incubation with increasing concentrations of ralaniten $(5-35 \mu \mathrm{M})$, all in the presence of R1881. DMSO is with R1881. Only DMSO (-) was not treated with R1881. (C) Transcript levels of KLK2, KLK3, and FKBP5 were normalized to levels of SDHA transcript from LNCaP and (D) LN95 cells treated with siRNA targeting MTF-1 with subsequent treatment increasing concentrations of ralaniten (5-35 $\mu \mathrm{M})$, all in the presence of R1881. DMSO is with R1881. Only DMSO (-) was not treated with R1881. Data presented as mean \pm SD and analyzed by two-way ANOVA with Sidak's test applied post hoc $(n=3$ independent experiments). (E) LNCaP cells were treated with scramble (control) or MTF1 siRNA prior to incubating with $0.1 \mathrm{nM}$ R1881 for 3 days before harvesting and analyzing for proliferation using the crystal violet assay. (F) LN95 cells treated with scramble (control) or MTF1 siRNA were incubated in charcoal-stripped serum in the absence of androgen or R1881 for 3 days before harvesting and analyzing cell growth with the crystal violet assay. Data presented as mean \pm SD and analyzed by two-way ANOVA with Sidak's test applied post hoc ( $n=3$ independent experiments). ${ }^{*} p<0.05$; ${ }^{* *} p<0.01 ; * * *<<0.001$; ${ }^{* * * *} p<0.0001$; n.s., not significant. 
To distinguish the ability of ralaniten to inhibit AR signaling in the context of knockdown of MTF-1, levels of expression of androgen-regulated genes (KLK2, KLK3/PSA, and FKBP5) were measured. Targeted knockdown of MTF-1 was repeated in LNCaP and LN95 cells treated with increasing concentrations of ralaniten and stimulated with R1881. Ralaniten inhibited the levels of expression of androgen-regulated genes in a dose-dependent manner regardless of knockdown of MTF-1 (Figure 5C,D). However, knockdown of MTF-1 significantly reduced expression levels of KLK2 and KLK3 in androgen-induced LNCaP cells (Figure 5C). Interestingly, this was not observed in LNCaP cells for the expression of FKBP5 or for any of these three genes (KLK2, KLK3, FKBP5) in LN95 cells (Figure 5D). The ability of ralaniten to inhibit androgen-induced cellular proliferation in $\mathrm{LNCaP}\left(\mathrm{IC}_{50} \mathrm{SCRM}\right.$ : 13.26 $\mu \mathrm{M}$; MTF-1: 11.25, $p=0.405$; Figure 5E), or androgen-independent proliferation of LN95 cells was not affected by knockdown of MTF1 (IC 50 SCRM: $16.14 \mu$ M; MTF-1: 13.52, $p=0.141$; Figure 5F).

\section{Materials and Methods}

\subsection{Chemicals and Compounds}

Metribolone (R1881) was purchased from AK Scientific (Mountainview, CA, USA); the antiandrogen bicalutamide was a kind gift from Mark Zarenda (AstraZeneca) and the antiandrogen enzalutamide was purchased from Omega Chem (Lévis, QC, Canada). Ralaniten was provided by Naeja-RGM (Edmonton, AB, Canada). SINT1 is a natural compound, and EPI-7170 and LPY-26 were synthesized by Raymond Andersen at UBC (Vancouver, BC, Canada). All other chemicals, including BADGE-2 $\mathrm{H}_{2} \mathrm{O}$, were purchased from Sigma Aldrich (St. Louis, MO, USA) unless stated otherwise.

\subsection{Cell Culture}

LNCaP cells were from Leland Chung (Cedars-Sinai Medical Center, Los Angeles, CA, USA) and maintained in phenol-red-free RPMI 1640 supplemented with 5\% FBS (VWR). LN95 cells were provided by Stephen Plymate (University of Washington). LN95 cells were maintained in RPMI 1640 medium supplemented with 10\% dextran-coated charcoal-stripped FBS. DU145 cells were from Victor Ling (British Colombia Cancer Agency, Integrative Oncology) in October 1998. Cells were maintained in DMEM with 10\% FBS and supplemented with $2 \mathrm{mM}$ L-glutamine and $1 \mathrm{mM}$ of sodium pyruvate. PC3 cells were purchased from ATCC and maintained in DMEM with 5\% FBS and supplemented with $2 \mathrm{mM}$ L-glutamine and $1 \mathrm{mM}$ of sodium pyruvate. LN95 cells were not authenticated in our laboratory, but were regularly tested to ensure that they were mycoplasma-free (VenorTMGeM Mycoplasma Detection kit, Sigma-Aldrich). LNCaP, PC3, and DU145 cells were authenticated by short tandem repeat analysis and tested to ensure that they were mycoplasma-free by DDC Medical. All cells used in the experiments were passaged in our laboratory for fewer than 3 months after resurrection.

\subsection{Microarray and GSEA Analysis}

Total RNA was extracted from LNCaP cells treated with ralaniten ( $35 \mu \mathrm{M})$, enzalutamide $(5 \mu \mathrm{M})$, bicalutamide $(10 \mu \mathrm{M})$, or DMSO vehicle and stimulated with either $1 \mathrm{nM}$ R1881 or EtOH vehicle. RNA was reverse-transcribed, and cDNA was hybridized to the GeneChip Human Transcriptome Array 2.0 from Affymetrix. RT-PCR, cDNA hybridization, and chip reading was carried out at CDRD's Target Validation Division at the University of British Columbia (Vancouver, BC, Canada; www.cdrd.ca (14 October 2014)). Analysis of raw signal output was done using GeneSpring software (version 13.1). Clustered data was generated by conducting a two-way ANOVA on data with the significance threshold set at 0.05 . The Benjamini-Hochberg correction was applied to reduce the false discovery rate (FDR).

Data generated from the microarray analysis was used to identify differences between AR antagonists. GSEA version 7.0 software (http://software.broadinstitute.org/gsea/ msigdb/index.jsp (5 December 2019) was used, and the difference in the expression levels 
between vehicle and drug treatment for each gene was analyzed based on the Molecular Signatures Database C2 sets (KEGG gene sets, c2.all.v6.2.symbols.gmt). The permutation number was set to 1000 . Those enrichment gene sets revealed by GSEA as exhibiting a nominal $p<0.05$ and FDR $<0.05$ were considered to indicate a statistically significant difference. The default parameters were used in the GSEA software.

\subsection{Reporter Assays}

LNCaP cells were transfected with reporter plasmids pMT1F-luciferase, pMT1Gluciferase, or pMT2-luciferase $(1 \mu \mathrm{g}$ /well) in serum-free, phenol-red-free media using Lipofectin (Invitrogen, Waltham, MA, USA). After $16 \mathrm{~h}$, cells were treated with SINT1 $(35 \mu \mathrm{M})$, LPY-26 $(35 \mu \mathrm{M})$, BADGE-2 $\mathrm{H}_{2} \mathrm{O}(35 \mu \mathrm{M})$, ralaniten $(35 \mu \mathrm{M})$, or DMSO vehicle. After $48 \mathrm{~h}$ of treatment, cells were lysed and analyzed for luciferase activity and normalized to protein expression. For dose-escalation experiments, LNCaP cells were transfected with the reporter plasmid pMT1F-luciferase, pMT1G-luciferase, or pMT2-luciferase in serumfree, phenol-red-free media using Lipofectin (Invitrogen). After $16 \mathrm{~h}$, cells were treated with increasing concentrations of ralaniten or DMSO vehicle. After $48 \mathrm{~h}$ of treatment, cells were lysed and analyzed for luciferase activity and normalized to protein expression.

\subsection{Xenografts and Animal Experiments}

All experiments involving animals were conducted in compliance with, and with the approval of, the Animal Care Committee of the University of British Columbia (A18-0077). Male NOD/SCID mice at 6 to 8 weeks of age were subcutaneously injected with LNCaP cells $\left(1 \times 10^{7}\right.$ cells $/$ site) using Matrigel (Becton Dickinson). Mice were castrated once tumors reached $\sim 100 \mathrm{~mm}^{3}$ and randomized into treatment groups to receive ralaniten (233 mg/kg), EPI-7170 (56.6 mg/kg) or vehicle control (5\% DMSO/1\% CMC/0.1\% Tween 80 ) once daily by oral gavage. Treatment began one week following castration. Mouse body weight and tumor volume (defined as volume $=$ length $\times$ width $\times$ height $\times 0.5236$ ) were regularly recorded, and tumors were excised $24 \mathrm{~h}$ after the last treatment. To analyze tumor gene expression, tumors were flash frozen, and $100 \mathrm{mg}$ was added to $1 \mathrm{~mL}$ TRIzol reagent (Invitrogen) and homogenized using a tissue homogenizer (MP Biomedicals). RNA was extracted and reverse-transcribed as detailed below.

\subsection{Gene-Expression and Dose-Escalation Experiments}

LNCaP, LN95, DU145, and PC3 cells were plated on 6-well plates in respective full media for $24 \mathrm{~h}$. Cells were serum starved for $24 \mathrm{~h}$ in serum-free RPMI 1640 prior to treatment. Cells were treated with ralaniten $(0.5-35 \mu \mathrm{M})$, enzalutamide $(0.5-20 \mu \mathrm{M})$, EPI-7170 $(0.5-20 \mu \mathrm{M})$, or DMSO vehicle in the absence of androgen stimulation. After $24 \mathrm{~h}$ of treatment, cells were harvested in $1 \mathrm{~mL}$ TRIzol reagent (Invitrogen). Total RNA was extracted using the RNeasy Micro Kit (Qiagen, Hilden, Germany), cleaned using an amplificationgrade DNase I Kit (MilliporeSigma, Burlington, MA 01083, USA) and reverse-transcribed using the High-Capacity RNA-to-cDNA Kit (Thermo Fisher Scientific, Waltham, MA, USA). Diluted cDNA and Platinum SYBR Green qPCR SuperMix-UDG with ROX (Invitrogen) were combined with gene-specific primers. Transcripts were measured by a qRT-PCR QuantStudio 6 Flex Real-Time PCR System (Applied Biosystems by Life Technology), and gene expression was normalized to the housekeeping gene SDHA. Gene-specific primer sequences are given in Supplementary Table S1.

\section{7. siRNA Knockdown Experiments}

Pooled siRNA against AR (L-003400-00-0005), MTF-1 (L-020078-00-0005), NRF2 (L003755-00-0005), and nontargeting control (D-001810-10-05) were purchased from Dharmacon Research (Layfayette, CO, USA). Lipofectamine RNAiMAX (Invitrogen) was used to transfect $10 \mathrm{nM}$ (AR, NRF2) or $15 \mathrm{nM}$ (MTF-1) of siRNA into cells in Opti-MEM serum-free media (Thermo Fisher Scientific). For experiments examining protein or mRNA expression, cells were plated on $10 \mathrm{~cm}$ or 6-well plates, respectively, in complete media for $24 \mathrm{~h}$ prior 
to transfection. After $24 \mathrm{~h}$, media were removed and replaced with Opti-MEM (Gibco) containing $10 \mathrm{nM}$ (AR, NRF2) or $15 \mathrm{nM}$ (MTF1) siRNA/transfection reagent complexes (Lipofectamine RNAiMAX Transfection Reagent, Invitrogen). Cells were pretreated with ralaniten $(5-35 \mu \mathrm{M})$, EPI-7170 $(5 \mu \mathrm{M})$, enzalutamide $(5 \mu \mathrm{M})$, or DMSO vehicle for $1 \mathrm{~h}$, followed by stimulation with $1 \mathrm{nM}$ R1881 or EtOH. Cells were harvested in $1 \mathrm{~mL}$ TRIzol, and RNA was extracted and reverse-transcribed as detailed above.

Protein lysates were harvested $24 \mathrm{~h}$ after R1881/EtOH treatment in RIPA buffer and separated on a 10\% SDS-PAGE gel and transferred to a PVDF membrane (Millipore LTD, Cork, IRL). AR was probed using an antibody obtained from Abcam (Ab198394). MTF-1 was probed using an antibody obtained from Invitrogen (PA5-55945). NRF2 was probed using an antibody obtained from Abcam (Ab137550). $\beta$-actin was used as a loading control, and membranes were probed using the mouse monoclonal anti- $\beta$-actin antibody (a5316 from Sigma).

For the proliferation assay, 5000 (LNCaP) or 7500 (LN95) cells were plated per well in 96-well plates in respective full media and incubated for $24 \mathrm{~h}$ to allow cells to attach. Media were removed and replaced with Opti-MEM containing 15 nM MTF1 siRNA or scrambled control for $24 \mathrm{~h}$. Treatments were prepared by serial dilution, and cells were pretreated with DMSO or ralaniten $(5-35 \mu \mathrm{M})$ for $1 \mathrm{~h}$ prior to stimulation with $0.1 \mathrm{nM}$ R1881 (LNCaP) or $1.5 \%$ charcoal-stripped serum (LN95). After $72 \mathrm{~h}$ post-treatment, cells were fixed in $4 \%$ paraformaldehyde (Electron Microscopy Sciences) and incubated with $0.1 \%$ crystal violet solution (Sigma). Dye was solubilized using a 1\% SDS solution, and absorbance was read using a VersaMax Microplate Reader (Molecular Devices) at $595 \mathrm{~nm}$.

\subsection{ROS Detection}

Total cellular ROS in cells was detected using the DCFDA/H2DCFDA-Cellular ROS kit from Abcam (ab11351) according to the manufacturer's instructions. LNCaP and LN95 cells plated on 96-well, black, clear-bottom plates were stained with DCFDA/H2DCFDA $(20 \mu \mathrm{M})$ for $30 \mathrm{~min}$ at $37^{\circ} \mathrm{C}$. After washing, cells were treated with tBHP $(75 \mu \mathrm{M})$, enzalutamide $(5 \mu \mathrm{M})$, ralaniten $(35 \mu \mathrm{M})$, EPI-7170 $(5 \mu \mathrm{M})$, or DMSO vehicle for $4 \mathrm{~h}$. Fluorescence was measured using the Infinite M1000 (Tecan) with excitation at $485 \mathrm{~nm}$ and emission at $535 \mathrm{~nm}$.

Mitochondrial superoxide was detected using MitoSOX Red from Sigma (M36008). LN95 cells were seeded on 8-well chamber slides and treated with tBHP, enzalutamide, ralaniten, EPI-7170, or DMSO vehicle as above for $4 \mathrm{~h}$ at $37^{\circ} \mathrm{C}$. Cells were then washed and stained with MitoSOX Red $(5 \mu \mathrm{M})$ diluted in HBSS/Ca/Mg buffer (Gibco, 14025092) for $10 \mathrm{~min}$ at $37^{\circ} \mathrm{C}$. Cells were washed gently three times in warm buffer before counterstaining with Hoechst 33342 (Sigma, 62249). Slides were mounted and visualized using a fluorescence microscope (Axio Imager.M2, ZEISS) at Ex/Em 350/461 (Hoechst) and 510/580 (MitoSOX Red).

\subsection{Statistical Analysis}

A one- or two-way ANOVA statistical test was used to determine significance for all comparisons unless specifically stated otherwise (Graphpad Prism, version 7.0). The $p$-value corrections were applied for all multiple comparisons (Tukey, Sidak, or Dunnett, as appropriate), and $p<0.05$ was considered statistically significant.

\section{Conclusions}

Despite initial response to targeted AR inhibition, most CRPC remains driven by continued AR transcriptional activity. Currently, there is no cure for CRPC, and patients will inevitably succumb to their disease. The existence of constitutively active AR-Vs, gain-of-function mutations within the AR-LBD, amplification of the AR gene, and intratumoral synthesis of androgens have been shown drive resistance to abiraterone and enzalutamide $[11,13,14]$. Additional evidence has implicated a genomic basis conferring an enhanced risk of prostate cancer. Germline mutations in a number of DNA-repair 
genes (especially BRCA2) have been associated with more aggressive disease and poor clinical outcomes [40]. Exploiting alterations in these genes allows their use as additional biomarkers to guide treatment decisions, best exemplified by the recent success of the Phase III clinical trial investigating the use of the PARP inhibitor olaparib compared to conventional AR-targeted therapies (NCT02987543) [41].

Furthermore, the discovery and development of small-molecule inhibitors that target the AR-NTD have significant potential to improve outcomes of CRPC patients who have progressed following treatment with existing AR-targeted therapies [16,18,19,42]. The prodrug of ralaniten (EPI-506) represents the first such compound to advance into clinical trials for heavily pretreated men with CRPC that had failed abiraterone and/or enzalutamide. This trial provided a proof of concept for the molecular scaffold of ralaniten, and showed signs of efficacy in spite of poor pharmacokinetics. These clinical studies have encouraged the clinical development of second-generation EPI compounds with improved potency and druglike qualities such as EPI-7386 (NCT04421222). Thus, ralaniten remains a useful tool compound to model and describe the mechanism of action of AR-NTD inhibitors. Here, we have begun to lay the groundwork for defining the molecular changes that occur following exposure to ralaniten. Specifically, we have shown that ralaniten: (1) was remarkably similar to bicalutamide and enzalutamide in its inhibition of expression of androgen-induced genes; (2) deviated substantially from AR-LBD inhibitors in de-repressing the expression of androgen-repressed genes, supporting the complexity of repression mechanisms that involve multiple mechanisms; and (3) uniquely induced the expression of metallothionein genes by a mechanism that was dependent on levels of MTF-1. Ralaniten induction of expression of the metallothionein genes was independent of the AR, thereby implying that this was an off-target and unique to ralaniten. Metallothioneins also play important roles in tumor growth, progression, and drug resistance, and may play a protective role due to being positively associated with malignancy and tumor grade in a number of human cancers $[29,43]$. Interestingly, this relationship seems to be at least partially reversed in prostate cancer, with expression of some metallothionein isoforms significantly downregulated or lost in advanced disease [44-47]. Here, we revealed that the efficacy of ralaniten as an inhibitor of AR-dependent growth was not adversely impacted by alterations in MTF1 and metallothionein.

Supplementary Materials: The following supporting information can be downloaded at: https:// www.mdpi.com/article/10.3390/cancers14020386/s1, Figure S1: Ralaniten induced metallothionein in prostate cancer cell lines with functional AR, Figure S2: whole western blots for Figure 4B, Figure S3: Ralaniten induced expression of metallothionein is independent of NRF2, Figure S4: whole western blots for Figure S3, Figure S5: Neither ralaniten nor EPI-7170 induce ROS generation, Table S1: Gene specific primer sequences for qRT-PCR experiments.

Author Contributions: Conceptualization, J.K.O. and M.D.S.; Methodology and Data Acquisition, J.K.O., S.J.L.T., N.R.M. and J.W.; Formal Analysis, J.K.O., S.J.L.T. and M.D.S.; Investigation, J.K.O. and S.J.L.T.; Resources, M.D.S.; Writing-Original Draft Preparation J.K.O. and M.D.S.; Writing-Review and Editing, M.D.S.; Visualization, J.K.O. and M.D.S.; Supervision, J.K.O. and M.D.S.; Funding Acquisition, M.D.S. All authors have read and agreed to the published version of the manuscript.

Funding: This work was supported by grants to M.D.S. from the National Cancer Institute of the National Institutes of Health (R01CA105304).

Institutional Review Board Statement: All experiments involving animals were conducted in compliance with, and with the approval of, the Animal Care Committee of the University of British Columbia (A18-0077, 25 March 2018).

Informed Consent Statement: Not applicable.

Data Availability Statement: All other relevant data are available from the corresponding author upon reasonable request. 
Conflicts of Interest: The authors declare the following competing interests: J.K.O., N.R.M., J.W. and M.D.S. are inventors of technology that was licensed by BC Cancer to ESSA Pharma Inc. M.D.S. has equity in and is a scientific advisor for ESSA Pharma Inc. Her interest was reviewed and managed by BC Cancer in accordance with its research conflict of interest policies. The author S.T. declares no conflict of interest.

\section{References}

1. Huggins, C.; Hodges, C.V. Studies on Prostatic Cancer. I. The effect of castration, of estrogen and androgen injection on serum phosphatases in metastatic carcinoma of the prostate. CA Cancer J. Clin. 1972, 22, 232-240. [CrossRef] [PubMed]

2. Harris, W.P.; Mostaghel, E.; Nelson, P.S.; Montgomery, B. Androgen deprivation therapy: Progress in understanding mechanisms of resistance and optimizing androgen depletion. Nat. Clin. Pract. Urol. 2009, 6, 76-85. [CrossRef]

3. Karantanos, T.; Corn, P.G.; Thompson, T.C. Prostate cancer progression after androgen deprivation therapy: Mechanisms of castrate resistance and novel therapeutic approaches. Oncogene 2013, 32, 5501-5511. [CrossRef] [PubMed]

4. Scher, H.I.; Sawyers, C.L. Biology of Progressive, Castration-Resistant Prostate Cancer: Directed Therapies Targeting the Androgen-Receptor Signaling Axis. J. Clin. Oncol. 2005, 23, 8253-8261. [CrossRef] [PubMed]

5. Scher, H.I.; Fizazi, F.S.; Taplin, M.E.; Sternberg, C.N.; Miller, K.; de Wit, R.; Mulders, P.; Chi, K.I.; Shore, N.D.; Armstrong, A.J.; et al. Increased Survival with Enzalutamide in Prostate Cancer after Chemotherapy. N. Engl. J. Med. 2012, 367, 1187-1197. [CrossRef]

6. Fizazi, K.; Scher, H.I.; Molina, A.; Logothetis, C.J.; Chi, K.N.; Jones, R.J.; Staffurth, J.N.; North, S.; Vogelzang, N.J.; Saad, F.; et al. Abiraterone acetate for treatment of metastatic castration-resistant prostate cancer: Final overall survival analysis of the COU-AA-301 randomised, double-blind, placebo-controlled phase 3 study. Lancet Oncol. 2012, 13, 983-992. [CrossRef]

7. Cai, C.; Chen, S.; Ng, P.; Bubley, G.J.; Nelson, P.S.; Mostaghel, E.A.; Marck, B.; Matsumoto, A.M.; Simon, N.I.; Wang, H.; et al. Intratumoral De Novo Steroid Synthesis Activates Androgen Receptor in Castration-Resistant Prostate Cancer and Is Upregulated by Treatment with CYP17A1 Inhibitors. Cancer Res. 2011, 71, 6503-6513. [CrossRef]

8. Robinson, D.; Van Allen, E.M.; Wu, Y.; Schultz, N.; Lonigro, R.J.; Mosquera, J.M.; Montgomery, B.; Taplin, M.E.; Pritchard, C.C.; Attard, G.; et al. Integrative Clinical Genomics of Advanced Prostate Cancer. Cell 2015, 165, 1215-1228. [CrossRef]

9. Chen, C.D.; Welsbie, D.S.; Tran, C.; Baek, S.H.; Chen, R.; Vassella, R.; Rosenfeld, M.G.; Sawyers, C.L. Molecular determinants of resistance to antiandrogen therapy. Nat. Med. 2004, 10, 33-39. [CrossRef]

10. Joseph, J.D.; Lu, N.; Qian, J.; Sensintaffar, J.; Shao, S.; Brigham, D.; Moon, M.; Maneval, E.C.; Chen, I.; Darimont, B.; et al. A Clinically Relevant Androgen Receptor Mutation Confers Resistance to Second-Generation Antiandrogens Enzalutamide and ARN-509. Cancer Discov. 2013, 3, 1020-1029. [CrossRef]

11. Taplin, M.E.; Bubley, G.J.; Ko, Y.J.; Small, E.J.; Upton, M.; Rajeshkumar, B.; Balk, S.P. Selection for androgen receptor mutations in prostate cancers treated with androgen antagonist. Cancer Res. 1999, 59, 2511-2515.

12. Antonarakis, E.S.; Lu, C.; Wang, H.; Luber, B.; Nakazawa, M.; Roeser, J.C.; Chen, Y.; Mohammad, T.A.; Chen, Y.; Fedor, H.L.; et al. AR-V7 and Resistance to Enzalutamide and Abiraterone in Prostate Cancer. N. Engl. J. Med. 2014, 371, 1028-1038. [CrossRef] [PubMed]

13. Antonarakis, E.S.; Lu, C.; Luber, B.; Wang, H.; Chen, Y.; Zhu, Y.; Silberstein, J.L.; Taylor, M.N.; Maughan, B.L.; Denmeade, S.R.; et al. Clinical Significance of Androgen Receptor Splice Variant-7 mRNA Detection in Circulating Tumor Cells of Men With Metastatic Castration-Resistant Prostate Cancer Treated With First- and Second-Line Abiraterone and Enzalutamide. J. Clin. Oncol. 2017, 35, 2149-2157. [CrossRef]

14. Jenster, G.; van der Korput, H.A.; Trapman, J.; Brinkmann, A.O. Identification of two transcription activation units in the N-terminal domain of the human androgen receptor. J. Biol. Chem. 1995, 270, 7341-7346. [CrossRef] [PubMed]

15. Jenster, G.; van der Korput, H.A.; van Vroonhoven, C.; van der Kwast, T.H.; Trapman, J.; Brinkman, A.O. Domains of the Human Androgen Receptor Involved in Steroid Binding, Transcriptional Activation, and Subcellular Localization. Mol. Endocrinol. 1991, 5, 1396-1404. [CrossRef]

16. Andersen, R.J.; Mawji, N.R.; Wang, J.; Wang, G.; Haile, S.; Myung, J.K.; Watt, K.; Tam, T.; Yang, Y.C.; Banuelos, C.A.; et al. Regression of Castrate-Recurrent Prostate Cancer by a Small-Molecule Inhibitor of the Amino-Terminus Domain of the Androgen Receptor. Cancer Cell 2010, 17, 535-546. [CrossRef]

17. Banuelos, C.A.; Tavakoli, I.; Tien, A.H.; Caley, D.P.; Mawji, N.R.; Li, Z.; Wang, J.; Yang, Y.C.; Imamura, Y.; Yan, L.; et al. Sintokamide A Is a Novel Antagonist of Androgen Receptor That Uniquely Binds Activation Function-1 in Its Amino-terminal Domain. J. Biol. Chem. 2016, 291, 22231-22243. [CrossRef] [PubMed]

18. Yang, Y.C.; Banuelos, C.A.; Mawji, N.R.; Wang, J.; Kato, M.; Haile, S.; McEwan, I.J.; Plymate, S.; Sadar, M.D. Targeting Androgen Receptor Activation Function-1 with EPI to Overcome Resistance Mechanisms in Castration-Resistant Prostate Cancer. Clin. Cancer Res. 2016, 22, 4466-4477. [CrossRef] [PubMed]

19. Myung, J.K.; Banuelos, C.A.; Fernandez, J.G.; Mawji, N.R.; Wang, J.; Tien, A.H.; Yang, Y.C.; Tavakoli, I.; Haile, S.; Watt, K.; et al. An androgen receptor N-terminal domain antagonist for treating prostate cancer. J. Clin. Investig. 2013, 123, 2948-2960. [CrossRef] [PubMed] 
20. Obst, J.K.; Wang, J.; Jian, K.; Williams, D.E.; Tien, A.H.; Mawji, N.R.; Tam, T.; Yang, Y.C.; Andersen, R.J.; Chi, K.N.; et al. Revealing Metabolic Liabilities of Ralaniten To Enhance Novel Androgen Receptor Targeted Therapies. ACS Pharmacol. Transl. Sci. 2019, 2, 453-467. [CrossRef]

21. Hiryama, Y.; Tam, T.; Jian, K.; Andersen, R.J.; Sadar, M.D. Combination therapy with androgen receptor N-terminal domain antagonist EPI-7170 and enzalutamide yields synergistic activity in AR-V7-positive prostate cancer. Mol. Oncol. 2020, 14, 2455-2470. [CrossRef] [PubMed]

22. Banuelos, C.A.; Ito, Y.; Obst, J.K.; Mawji, N.R.; Wang, J.; Hirayama, Y.; Leung, J.K.; Tam, T.; Tien, A.H.; Andersen, R.J.; et al Ralaniten Sensitizes Enzalutamide-Resistant Prostate Cancer to Ionizing Radiation in Prostate Cancer Cells that Express Androgen Receptor Splice Variants. Cancers 2020, 12, 1991. [CrossRef] [PubMed]

23. Leung, J.K.; Imamura, Y.; Kato, M.; Wang, J.; Mawji, N.R.; Sadar, M.D. Pin1 inhibition improves the efficacy of ralaniten compounds that bind to the N-terminal domain of androgen receptor. Commun. Biol. 2021, 4, 381. [CrossRef] [PubMed]

24. Tien, A.H.; Sadar, M.D. Cyclin-dependent kinase 4/6 inhibitor palbociclib in combination with ralaniten analogues for the treatment of androgen receptor-positive prostate and breast cancers. Mol. Cancer Ther. 2021. [CrossRef]

25. Bchler, R.H.; Kagi, J.H. Human hepatic metallothioneins. FEBS Lett. 1974, 39, 229-234. [CrossRef]

26. Shock, H.; Demoor, J.M.; Kennette, W.A.; Collins, O.M.; Koropatnick, J. Zinc-Metallothionein Levels Are Correlated with Enhanced Glucocorticoid Responsiveness in Mouse Cells Exposed to $\mathrm{ZnCl}(2), \mathrm{HgCl}_{(2)}$, and heat shock. Toxicol. Sci. 2001, 76, 67-76. [CrossRef]

27. Wei, H.; Desouki, M.M.; Lin, S.; Xiao, D.; Franklin, R.B.; Feng, P. Differential expression of metallothioneins (MTs) 1,2, and 3 in response to zinc treatment in human prostate normal and malignant cells and tissues. Mol. Cancer 2008, 7, 7. [CrossRef] [PubMed]

28. Dalton, T.P.; Li, Q.; Bittel, D.; Liang, L.; Andrews, G.K. Oxidative Stress Activates Metal-responsive Transcription Factor-1 Binding Activity. Occupancy in vivo of Metal response Elements in the Metallothionein-I Gene Promoter. J. Biol. Chem. 1996, 271, 26233-26241. [CrossRef]

29. Si, M.; Lang, J. The roles of metallothioneins in carcinogenesis. J. Hetmatol. Oncol. 2018, 11, 107. [CrossRef]

30. Bainbridge, M.N.; Warren, R.L.; Hirst, M.; Romanuik, T.; Zeng, T.; Go, A.; Delany, A.; Griffith, M.; Hickenbotham, M.; Magrini, V.; et al. Analysis of the prostate cnacer cell line LNCaP transcriptome using a sequence-by-synthesis approach. BMC Genom. 2006, 7, 246. [CrossRef]

31. Nelson, P.S.; Clegg, N.; Arnold, H.; Ferguson, C.; Bonham, M.; White, J.; Hood, L.; Lin, B. The program of androgen-responsive genes in neoplastic prostate epithelium. Proc. Natl. Acad. Sci. USA 2002, 99, 11890-11895. [CrossRef] [PubMed]

32. Romanuik, T.L.; Wang, G.; Holt, R.A.; Jones, S.J.M.; Marra, M.A.; Sadar, M.D. Indentification of novel androgen-responsive genes by sequencing of LongSAGE libraries. BMC Genom. 2009, 10, 476. [CrossRef] [PubMed]

33. Grosse, A.; Bartsch, S.; Baniahmad, A. Androgen receptor-mediated gene repression. Mol. Cell. Endocrinol. 2012, 352, 46-56. [CrossRef]

34. Andrews, G.K. Regulation of Metallothionein Gene Expression by Oxidative Stress and Metal Ions. Biochem. Pharmacol. 1999, 59, 95-104. [CrossRef]

35. Coyle, P.; Philcox, J.C.; Carely, L.; Rofe, A.M. Metallothionein: The multipurpose protein. Cell. Mol. Life Sci. 2002, 59, 627-647. [CrossRef]

36. Sahu, B.; Laakso, M.; Pihlajamaa, P.; Ovaska, K.; Sinielnikov, I.; Hautaniemi, S.; Janne, O.A. FoxA1 specifies unique androgen and glucocorticoid receptor binding events in prostate cancer cells. Cancer Res. 2013, 73, 1570-1580. [CrossRef]

37. Cleutjens, C.B.; Steketee, K.; van Eekelen, C.C.; van der Korput, J.A.; Brinkmann, A.O.; Trapman, J. Both androgen receptor and glucocorticoid receptor are able to induce prostate-specific antigen expression, but differ in their growth-stimulation properties of LNCaP cells. Endocrinology 1997, 12, 5293-5300. [CrossRef] [PubMed]

38. Liang, G.Y.; Lu, S.X.; Xu, G.; Liu, X.D.; Li, J.; Zhang, D.S. Expression of metallothionein and Nrf2 pathway genes in lung cancer and cancer-surrounding tissues. World J. Surg. Oncol. 2013, 11, 199. [CrossRef]

39. Schwarz, M.; Lossow, K.; Kopp, J.F.; Schwerdtle, T.; Kipp, A.P. Crosstalk of Nrf2 with the Trace Elements Selenium, Iron, Zinc, and Copper. Nutrients 2019, 11, 2112. [CrossRef]

40. Pritchard, C.C.; Mateo, J.; Walsh, M.F.; De Sarkar, N.; Abida, W.; Beltran, H.; Garofalo, A.; Gulati, R.; Carreira, S.; Eeles, R.; et al. Inhereted DNA-Repair Gene Mutations in Men with Metastatic Prostate Cancer. N. Engl. J. Med. 2016, 375, 443-453. [CrossRef]

41. de Bono, J.; Mateo, J.; Fizazi, K.; Saad, F.; Shore, N.; Sandhu, S.; Chi, K.N.; Sartor, O.; Agarwal, N.; Olmos, D.; et al. Olaparib for Metastatic Castration-Resistanct Prostate Cancer. N. Engl. J. Med. 2020, 382, 2091-2102. [CrossRef]

42. Antonarakis, E.S.; Chandhasin, C.; Osbourne, E.; Luo, J.; Sadar, M.D.; Perabo, F. Targeting the N-Terminal Domain of the Androgen Receptor: A New Approach for the Treatment of Advanced Prostate Cancer. Oncologist 2016, 21, 1427-1435. [CrossRef]

43. Jasani, B.; Schmid, K.W. Significance of metallothionein overexpression in human tumours. Histopathology 1997, 31, 211-214. [CrossRef]

44. Han, Y.C.; Zheng, Z.L.; Zuo, Z.H.; Yu, Y.P.; Chen, R.; Tseng, G.C.; Nelson, J.B.; Luo, J.H. Metallothionein 1 h tumour suppressor activity in prostate cancer is mediated by euchromatin methyltransferase 1. J. Pathol. 2013, 230, 184-193. [CrossRef] 
45. Garrett, S.H.; Sens, M.A.; Shukla, D.; Flores, L.; Somji, S.; Todd, J.H.; Sens, D.A. Metallothionein Isoform 1 and 2 Gene Expression in the Human Prostate: Downregulation of MT-1X in Advanced Prostate Cancer. Prostate 2000, 43, 125-135. [CrossRef]

46. Henrique, R.; Jeronimo, C.; Hoque, M.O.; Nomoto, S.; Carvalho, A.L.; Costa, V.L.; Oliveira, J.; Teixeira, M.R.; Lopes, C.; Sidransky, D. MT1G Hypermethylation Is Associated with Higher Tumor Stage in Prostate Cancer. Cancer Epidemiol. Biomark. Prev. 2005, 14, 1274-1278. [CrossRef] [PubMed]

47. Prueitt, R.L.; Yi, M.; Hudson, R.S.; Wallace, T.A.; Howe, T.M.; Yfantis, H.G.; Lee, D.H.; Stephens, R.M.; Liu, C.G.; Calin, G.A.; et al. Expression of MicroRNAs and Protein-Coding Genes Associated With Perineural Invasion in Prostate Cancer. Prostate 2008, 68, 1152-1164. [CrossRef] [PubMed] 